\title{
The Importance of Global Business Hubs on Internationalizing SMEs: an empirical analysis of psychic and geographic distance. Pascal Wild
}

\author{
I The new technical capabilities associated with ICT, and some components of the work \\ of states, have together constituted scales other than the national as strategic today. " \\ Saskia Sassen, Professor, \\ Columbia University
}

\begin{abstract}
This article investigates the influence of psychic and geographic distance, as well as country and market-related variables, on the preference of high-technology small and medium-sized enterprises (SMEs) to connect with, and settle in major business hubs. Literature in the field of SME internationalization and international entrepreneurship increasingly emphasizes a network approach in which the characteristics and linkages of the internationalizing firm's network are studied. We aim to contribute to this network-based internationalization research by integrating a further element present in complex social and technical networks: network hubs. Hubs are highly connected nodes within a network. In global business, hubs can be defined as business sites that have a high interconnection with the world economy through tremendous flows of goods and capital. The empirical findings of our research suggest that internationalizing high technology SMEs tend to connect with, or settle in to foreign market business hubs, when focal markets are more distant from their home market. These findings are significant for both geographic and psychic distances between home and focal markets.
\end{abstract}

\section{Introduction}

Small and Medium Enterprises (SMEs) are considered the backbone of most economies since they account for a large majority of firms and employ a large amount of the working population. This is the case for North America, Europe as well as for China, where SMEs account for $99 \%$ of firms. They employ two-thirds of the workforce in the case of the first two, and $80 \%$ in the case of China (Arnone \& Deprince, 2016; Munir et al., 2017; SBA, 2020). In recent years, many SMEs have dramatically increased their involvement in international business activities. This is particularly true for the many highly innovative producing and servicing SMEs from so-called small and open economies (SMOPECs), such as Australia, Switzerland and the Scandinavian countries, in which the limited size of the home market does not ensure enough potential for growth and survival. In Switzerland, for example, most internationalizing SMEs with less than 250 full-time equivalents belong to highly technical and innovative producing and servicing sectors, such as engineering, chemicals, and medical technologies
(Baldegger \& Wild, 2019). Through the wildfire growth of the internet and IT businesses in the early 1990's, the internationalization of SMEs was amplified even more. Compared to larger-sized traditional multinational enterprises (MNEs), SMEs often lack sufficient resources and capabilities when they want to engage in international trade (Talebi et al., 2017). Holmlund and Kock (1998) explain that in various aspects, such as managerial, supervisory, production, and employee levels, SMEs lack the skills and expertise needed in order to be involved in international trade.

Extant literature on SME internationalization discusses distance as a major liability for a firm to enter new markets (Johanson \& Wiedersheim-Paul, 1975; Johanson and Vahlne, 1977; Erramilli, 1991; Baldegger and Wyss, 2007; Ojala \& Tyrväinen, 2007). In traditional views oriented on MNEs than internationalizing SMEs, distance is perceived to raise transaction costs, and bring uncertainty due to lacking information about local foreign market conditions (Rugman \& Verbeke, 1993; Mark Casson 2013). The neoclassical approach is based on an underlying assumption that firms are 


\section{The Importance of Global Business Hubs on Internationalizing SMEs: an empirical analysis of psychic and geographic distance.}

\section{Pascal Wild}

acting in a fully rational behavior and maximizing their income by perfectly exploiting markets. Additionally, it did not take the rising population of small internationalizing organizations into account (Wild, 2018). Nevertheless, trade liberalization, better communication, and internet-related business opportunities lead to a rising number of ever more global start-ups and SMEs.

Contemporary approaches to SME internationalization are instead based on a behavioral theory of the firm (Johanson \& Vahlne, 1977, 2009), and analyze the patterns of SME internationalization from a process and network perspective. The network perspective focuses on non-hierarchical systems where firms invest in international activities in order to strengthen or defend their network position (Rialp \& Rialp, 2001). In this approach, a network is seen as a dyadic business relationship formed between two or more actors (Anderson et al., 1994; Senik et al., 2011). It is assumed that understanding the role played by the set of ties in which a small firm is embedded will contribute to a better explanation of its international behavior (Styles et al., 2006; Zain \& Ng, 2006; Al-Laham \& Souitaris, 2008; Johanson \& Vahlne, 2009; Jones et al., 2011; Galkina \& Chetty, 2015). Networks are discussed as they influence a SMEs ability to recognize international opportunities (Chetty \& Campbell-Hunt, 2004; Coviello, 2006; Gilmore et al., 2006; Galkina \& Chetty, 2015; Zhang et al., 2016). They are also assumed to influence the speed and performance of a SME's internationalization process (Musteen et al., 2010; Hohenthal et al., 2014).

In the traditional Uppsala model from the 1970's, also known as the Nordic school, SME internationalization was considered as a gradual, stepwise process in which both commitment to foreign markets, as well as the distance of the foreign marketplaces, seemed to steadily increase (Johanson \& Vahlne, 1977). Starting mostly in geographically and culturally close (proximate) markets, the acquisition of experiential knowledge and organizational learning was assumed to be crucial to a SME's progress into more and more distant foreign markets (Johanson \& Vahlne, 1977). In Johanson and Vahlne's $(1990,2003,2009)$ subsequent contributions, the authors shifted away from a firm-centric approach towards a network-perspective. This paradigm shift was caused as a result of growing evidence for a new type of internationalization behavior, which was challenging the identified patterns of the Nordic school. Some SMEs, in particular highly innovative and competitive ones, seemed to skip important steps of the gradual process, and instead turn into internationally or globally operating companies within a short time interval (Oviatt \& McDougall, 1994; Knight \& Cavusgil, 1996). Many of the SMEs that were observed in the early 90s, belonged to the growing ICT branch, and could be classified as Start-ups. Their international or global scope of business activities was inherent from inception or very soon thereafter, and thus these firms were labelled as "born global" (Madsen \& Servais, 1997; Moen, 2002), global start-ups (Oviatt \& McDougall, 1994), instant exporters, instant global entrepreneurship (McAuley, 1999; Katz et al., 2003), or international new ventures (McDougall, 1994; Zahra, 2005), just to name a few definitions.

The network formation process along with entrepreneurial social interactions were cited among the main reasons for this particular type of internationalized SME (Oviatt \& McDougall, 1994; Bell et al., 1998; Zahra, 2005; Zhou et al., 2007). Zahra (2005) argued that these firms' networks provided them with better international opportunities. Freeman and coauthors (2006) highlighted the importance of an entrepreneur's private network ties that allow bornglobal firms to access important foreign clients. For Zhou et al. (2007), the home-based social networks of born-global companies provides them with advice and experiential learning, as well as trust and solidarity, in addition to knowledge about foreign market opportunities.

In their revisited Uppsala model, Johanson and Vahlne (2009), took account of these phenomena and fully revised their view of SMEs' internationalization process according to a network perspective. They replaced the firms' market commitment by its network position, and justified this change with the following arguments: "we now assume that the internationalization process is pursued within a network. Relationships are characterized by specific levels of knowledge, trust, and commitment that may be unevenly distributed among the parties involved, and hence they may differ in how they promote successful internationalization".

However, despite the increased emphasis of a network perspective on SME internationalization, understanding the role of SMEs' network characteristics remains partial and fragmented (Bruneel \& De Cock, 2016; Stoian et al., 2017; Ribau et al., 2018). Hence, numerous scholars have begun to construct empirical and theoretical applications for more fundamental theories about social networks (Knox et al. 2006; Ellis, 


\section{The Importance of Global Business Hubs on Internationalizing SMEs: an empirical analysis of psychic and geographic distance.}

\section{Pascal Wild}

2011; Galkina \& Chetty 2015; Masiello \& Izzo, 2019; Yamin \& Kurt, 2018). We aim to contribute to this work by introducing an important element of complex social networks to the network-based research on SME internationalization, namely, with the notion of "network hubs". Therefore, we first discuss the concept as well as the role of network hubs in global business. Then, we linking the current theories on network hubs with the process of SME internationalization, in which the relevance of distance plays an important role and is starting to be discussed heavily. We then state our hypotheses based on empirically tests involving the case of 609 internationalizing hi-tech SMEs from Switzerland.

\section{Theoretical overview and hypothesis development}

Hubs are an important element in theories about complex social networks. Barabasi and Reka (1999) discovered that most social networks share the common feature of a power law distribution in which the number of connections rises exponentially. They argued that most of the world's real networks are open systems in which the number of new vertices to the system are continuously increasing throughout the lifetime of the network. Instead of connecting randomly, new vertices tend to connect to nodes that are already well connected. Hence, the preferential attachment of new vertices to already well-connected vertices. Previously this was called the 'Matthew Effect' by Robert K. Merton (1968) regarding the effects of accumulated advantage in scientific research. It is also described as "the rich are getting richer" phenomenon (Caldarelli et al., 2002), which leads to the development of highly connected hubs in social as well as technical networks (Barabasi \& Reka, 1999).

Hubs are an important subject of research in the field of economic geography. In this field of research, they describe the centre for certain kinds of industrial activity, for example research (Philip et al., 2015), financial activities (Poon et al., 2015), car assembly (Edgington, 2015), or others. Mostly, these centres are concentrated in a geographically limited area, that is densely populated by firms and individuals, such as a city. Such territorial nodes, essential to the sustainable development of world trade and financial flows along the global value chain, are defined by contemporary literature in economics and sociology as "global cities" (Sassen, 1994, 2005; Friedmann, 1995). Due to their high concentration of foreign MNCs and affiliates, such cities provide an exceptional density of highly specialized service firms such as lawyers, financial institutions, and advertising agencies, and bring together various types of entrepreneurship capacities linking their hinterland to regional and world markets (Friedmann, 1995; Scott, 2001; Olds \& Yeung, 2011). At the heart of global city research lies a seemingly paradoxical trend, that is increasingly being confirmed over the last three decades: economic activities are getting dispersed around the world, while simultaneously control and command functions over these activities have been ever more centralised and integrated into some leading cities (Sassen, 1991).

\subsection{Connectivity and SMEs links to global business hubs}

The global control exercised by MNCs in their headquarters has made possible the emergence of a variety of producer and financial services (Alderson \& Beckfield, 2004). Globally operating service-providing firms in the fields of Accounting, Advertising, Banking and Finance as well as Law, so-called Advanced Producer Services (APS) offer worldwide assistance to MNEs for executing their power and control (Hoyler et al., 2008; Pereira \& Derudder, 2010; Jacobs et al., 2011; Taylor, 2012). These APSs are MNEs themselves, and in that sense, they locate their business wherever they detect a certain demand for the services they provide. By collecting information about an APS's global network of branches, information on the global dispersion of major MNEs, and where global control is exercised can be obtained. Hence, various scholars have traced intercity networks within these globally acting MNEs (Taylor et al., 2002; Taylor, 2001, 2012; Hoyler et al., 2008). Following this line of thought, a roster of global cities can be drawn on a geographic map of globalization, that maps the office locations of these global APS firms servicing MNCs. Thus, a city's connectivity is the product of service values (the number APS headquarters and their importance in their respective firm hierarchies) inherent in that city.

Connectivity might therefore not only be of interest for MNCs, but also for internationalizing SMEs. Some evidence for this exists in studies on international entrepreneurship. Acs and co-authors (2008) observed higher entrepreneurial activity in global cities when compared to the rest of a country's locations. Iammarino and McCann (2015) pointed out that for internationalizing companies, location is key in order to maintain access to the latest technologies and trigger interorganizational innovation. In turn, they also observed the important economic impact that subsidiaries of international firms have on the city in which they settle. Considering the liability of 


\section{The Importance of Global Business Hubs on Internationalizing SMEs: an empirical analysis of psychic and geographic distance.}

\section{Pascal Wild}

internationalizing SMEs given by their limited resources, lack of skills and competencies in foreign markets (Eriksson et al., 2006; Domingues \& Mayrhofer, 2017), these firms' demand for external services might increase with geographic expansion (Ruzzier \& Antoncic, 2007; Senik et al., 2011). Following this line of thought, we argue that internationalizing SMEs might primarily be connected to global cities (hereafter called global business hubs), functioning as global business hubs that host many highly specialized service-firms. Thus, we state the following hypothesis:

H1: The higher the connectivity-rate of a global business hub with the world economy, the higher the share of foreign internationalizing SMEs using the hub's business networks.

\subsection{Geographic distance and SMEs links to global business hubs}

Geographic distance is a significant factor in the selection of firms' target countries for internationalization. According to the Nordic school of entrepreneurship, distance increases the uncertainty about an outcome of an action. In that regard, a gradual internationalization process does not only occur through increasing involvement of foreign activities, but also in an increasing the distance between home and foreign markets (Johanson \& Vahlne, 1977).

Despite the rising phenomenon of international new ventures (INVs), gradually internationalizing firms still tend to be the norm. According to Clark and Pugh (2001), the first three foreign countries that British firms enter markets in are significantly closer geographically than subsequent ones. The same was observed among SMEs in New Zealand that tend to enter the nearby Australian market first, before venturing towards more distant ones (Chetty, 1999). Even among sectors with a relatively high population of INVs, such as the software industry, evidence was found that they enter first into countries geographically proximate. This is due to the fact that most software products require intensive relationships with the customer, which is favoured through short geographic distance (Moen et al., 2004; Ojala \& Tyrväinen, 2006). Ojala and Tyrväinen (2006), concluded after in-depth literature review of distance related to SME internationalization, that closer countries have a more familiar environment in terms of language, culture, and business practices, which makes it is less expensive to operate in nearby countries.

Considering the literature, we suggest the necessity for internationalizing SMEs to connect to spatial network hubs rises with geographic distance between home and focal markets. The high density of APS firms and intellectual capital available in global business hubs does not uniquely enable MNEs to headquarter as a way of exercising their control and command functions. There is likewise benefit with distant internationalizing SMEs if they connect effectively with important foreign market actors. Thus, we hypothesize that internationalizing hi-tech SMEs in geographically distant markets are more likely to be connected to market network hubs, either by having their own representation office, or by third-party firms that serve as representatives. With this line of thought, we state the following hypothesis:

H2: The greater the geographic distance between a SME's home and focal market, the higher the share of foreign internationalizing SMEs that dispose over network links to the focal market's global business hub.

\subsection{Psychic distance and SMEs links to global business hubs}

The concept of psychic distances in relation to the internationalization of firms dates back to the works of Beckerman (1956), and studied patterns of intraEuropean trade. Psychic distance, defined as the sum of "factors preventing or disturbing the flows of information between firm and market" (Johanson \& Wiedersheim-Paul, 1975), increases the more a company is confronted with unfamiliar or even unknown market conditions. Differences in language, laws and rules, persist, but triggers of psychic distances are also considered according to cultural and social milieu.

Dow (2000) describes the effects of psychic distance on an internationalizing firm as decreasing after having dealt with the first foreign markets, while it remains an important and decisive factor in a company's process of market selection. The cultural framework of a society frames all kinds of economic activities within the society, and influences both policies and regulations (Wiliamson, 2000; De Clercq et al., 2014). This difference already impacts internationalization projects for physically close markets (O'Grady \& Lane, 1996). Considering the context of a middle-European country such as Switzerland, many rather physically close countries such as in Northern Africa or Eastern Europe, nevertheless dispose a high psychic distance, whereas physically distant markets such as Australia and New 


\section{The Importance of Global Business Hubs on Internationalizing SMEs: an empirical analysis of psychic and geographic distance.}

\section{Pascal Wild}

Zealand remain in a rather close psychic distance to their home market (Wild, 2019). While analyzing patterns of internationalization among SMEs from New Zealand, Chetty and Campbell-Hunt (2004) found that next to the geographically nearby market of Australia, New Zealand's SME prefer to internationalize into the rather distant market of the United Kingdom, instead of into closer markets of (Latin and North-) America or on the Asian continent. The main reason for this is the closer psychic distance they have to British markets.

Considering the literature, we suggest that the necessity of internationalizing SMEs to connect with spatial network hubs rises with the psychic distance between home and focal markets. SMEs in psychically distant markets need supportive assistance that is to be found in its highest density in the business networks of global cities. Thus, we hypothesize that internationalizing hitech SMEs in psychically distant markets are more likely to be connected through the markets' network hubs, either through their own representation office, or by third-party firms:

H3: The greater the psychic distance between a SME's home and focal markets, the higher the share of foreign internationalizing SME that dispose over network links to the focal market's global business hub.

\subsection{The empirical model}

The figure below depicts two independent variables, geographic and psychic distance, that positively influence the dependent variable, labelled Global Business Hub Ratio. The dependent variable is the ratio of SMEs with a connection to major global business hubs, among those who declared having business activities in the related world region. We consider a relative share of SMEs, since most of them disperse their activities among a few world regions without being a "truly" global player (Baldegger \& Wyss, 2007; Onkelinx \& Sleuwaegen, 2010; Baldegger \& Wild, 2019).

Controls were included for the effect of political freedom as well as the city population of the global business hub. The effect of political freedom on a nation's economy has been the topic of many debates. The level of a nations' political freedom indicates the extent to which its citizens are granted civil liberties and political rights (Gastil, 1991). Individuals who dispose over a high degree of political freedom must live in a nation that allows them to participate in the formation of public policies (Gibson, 1993), benefit from freedoms of speech, press, expression, and assembly (Dheer, 2017), and exercise their legal rights (Wu \& Davis, 1999).

Since economic, social, and political uncertainty in a society are generally decreased through the existence of political freedom, some scholars have described the positive effect on an economy of increased competition and venture creation (Goodell \& Powelson, 1982; Sirowy \& Inkeles, 1990). Investment, whether local or foreign, is encouraged through democratic governments that offer protection of property rights and low taxation (Axiala \& Fabro, 2009). Further empirical evidence supports this argument stating that more political freedom also increases entrepreneurial activity and enhances economic growth (Scully, 1988; Kurzman et al., 2002; Doucouliagos \& Ulubasoglu, 2008).

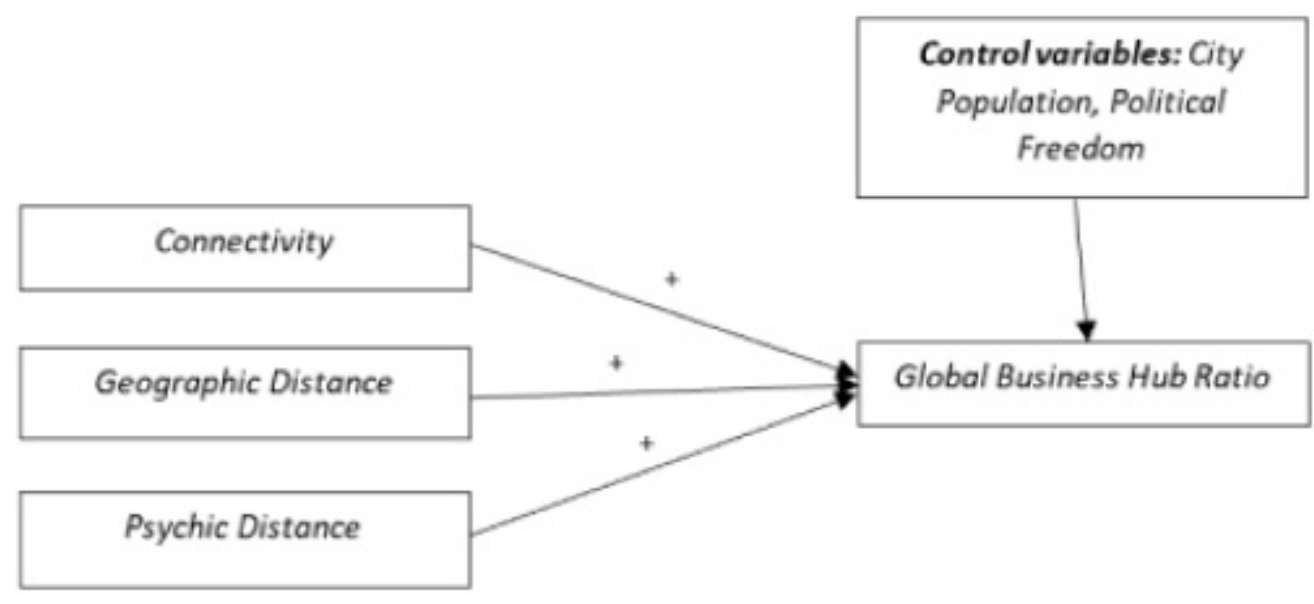

Figure 1. Proposed model of the relative share of SMEs with network links to a global business hub (Internationalizing SMEs per hub) 


\section{The Importance of Global Business Hubs on Internationalizing SMEs: an empirical analysis of psychic and geographic distance. \\ Pascal Wild}

The population of a city is, on one hand, an indicator of the market size in a business-to-customer market. Internationalizing firms tend to invest where the market size is of a certain importance. On the other hand, empirical evidence exists of a positive correlation between the size of a population and opportunities for new business formation (Van Stel et al. 2005; Acs et al.2008).

\section{Methodology}

To test these three hypotheses, data was compiled from four different sources: (a) the Swiss International Entrepreneurship Survey (SIES) of 2016, (b) Hofstede's (2001) cultural indices database, (c) Freedom House's political freedom index dataset, and (d) the database on cities' population from the United Nations (2019) population division.

The SIES dataset comprised data on internationalizing SMEs in Switzerland that were collected in a crosssectional study design in 2016. The SMEs were controlled for the following criteria: (a) minimum of 5 and a maximum of 249 employees, (b) headquartered in Switzerland, and (c) minimum of $20 \%$ turnover in foreign countries. The data was provided by Dun \& Bradstreet business intelligence and led to a total of 609 valid respondent SMEs. In the following sections, the model's variables are explained in more detail.

\subsection{Dependent variable}

The global business hub ratio represents the percentage of firms composed of direct and/or indirect links to a world region's global city, which are among the companies that generate turnover in the relative world region. Direct links mean that the company has direct representation, such as an owned branch, point of purchase, or office space. Indirect links are third-party firms that represent SMEs, such as a trade or a sales intermediary and partner-firms. This measure is calculated for every global city rated as Alpha by the GaWC (2012). In the SIES, the surveyed SMEs are indicated on a matrix of fourteen world regions and an ordinal scale of six categories based on "share of foreign sales as a \% of total revenues" and how much revenue is generated in each world region. The companies were counted as being "active" in a world region if they generated a minimum of $5 \%$ turnover from it.

Global Business Hub Ratio = [number of SMEs indicating direct and/or indirect links to a global business hub] / [number of SMEs indicating turnover from a global business hub's world region]

The subregions as defined by the United Nations Statistics Division (UNSD), based on M.49 standard area codes for statistical purposes (United Nations, 2018), were grouped into twelve major world regions. The stages of economic development as defined in the Global Competitiveness Report (Schwab et al., 2016) served to enable subdivisions and groupings of these subregions.

\subsection{Independent variables}

Taylor (2001) made an attempt to calculate the measure of cities' connectivity with the global economy. The variable named "connectivity" is the product of service values for a city with each other city for all APS firms. The data collection for this variable was carried out by the GaWC utilizing 100 office networks of service firms in accounting, advertising, banking/finance, insurance, law, and management consultancy that operate globally (Taylor, 2001). These firms were chosen due to having offices in at least 15 different cities in the major globalized regions of Northern America, Western Europe and Asia-Pacific.

The service value for firm $j$ in city $i$ is allocated $v i j$, and $m$ is the APS firm. The basic rational unit of measurement defining the relation between cities $a$ and $b$ in terms of firm $j$ is given by:

The aggregate cities' interlock between cities is given by:

$$
\mathbf{r}_{a b j}=\mathbf{V}_{a j} \mathbf{V}_{b j}
$$

For each city there are n-1 such interlocks and the network connectivity for a city is given by:

$$
\mathrm{r}_{a b}=\sum_{j} r_{a b j}
$$

Where $C$ is the network connectivity of city $a$.

$$
C_{\alpha}=\sum \mathrm{i} r \text { ai where } \mathrm{a} \neq \mathrm{i}
$$

With this formula, city $a$ is related to all other cities within the network through its companies. It measures the integration degree of a city into the world city network. 


\section{The Importance of Global Business Hubs on Internationalizing SMEs: an empirical analysis of psychic and geographic distance.}

\section{Pascal Wild}

The geographic distance between Switzerland and global business hubs was measured using the linear distance between Zurich, Switzerland's biggest and economically most powerful city, and the respective global cities. The value represents the distance in Kilometers.

Among the measures used in international business and multinational enterprise literature, we find principally Sethi's (1971) clustering of world markets, and Hofstede's cultural difference dimensions (Dow, 2000). The most extensive and comprehensive empirical research done to date on the cultural dimension relevant to work organizations is probably the one conducted by Hofstede, published in 1980 and 1984 (Benito \& Gripsrud, 1992). The fact that Hofstede collected his data within a large multinational enterprise and for more than fifty subsidiaries made the data relatively robust. Only employees in similar occupations from the same multinational enterprise were compared. This gave him the opportunity to control for bias from different occupational positions and organizational practices (Hofstede, 1980, 1984; Benito \& Gripsrud, 1992). As pointed out by Kogut and Singh (1988), Hofstede's work is impressive in its sample size and with the reliability of scores over time. He found that differences between national cultures vary along four dimensions: uncertainty avoidance, individuality, power distance, and masculinityfemininity. The codification of cultural traits along numerical indexes made it possible to compare relative differences between countries. In the composite index, as established by Kogut and Singh (1988), the deviation along each of the four cultural dimensions builds the starting point for measuring the distance. The deviations are corrected for differences in the variance of each dimension, and then arithmetically averaged (Kogut \& Singh, 1988; Benito \& Gripsrud, 1992). Cultural distance $\mathrm{CDj}$ is the product of the following equation, as used in this study:

$$
\mathrm{CD}_{i}=\sum_{i=1}^{4}\left[\left(I_{i j}-I_{i N}\right) 2 / V_{i}\right] 4
$$

where

$I_{i j}=$ index value for cultural dimension I of country $j$; $V_{i}=$ variance of the index for dimension $i$;

$$
\mathrm{N}=\text { home country }
$$

\subsection{Control variables}

City populations were added to the model in order to control for effects due to the size of a global business hub. The measures were selected from the 2014 database of the United Nations (United Nations, Department of Economic and Social Affairs, Population Division, 2014).

The most commonly used index in order to measure political freedom in countries is provided by Freedom House (Dawson, 1998; Far et al., 1998, Gerring et al., 2005). Accordingly, political freedom is measured along the dimensions of political rights and civil liberties. Political rights include the population's possibility to vote, participate in fair elections, and their general involvement in political decision making. Civil liberties capture equality of opportunities, freedom of expression, assembly, religion and so forth. The average value of both indexes was calculated and implemented as a control variable. Since each index is measured on a scale between 1 and 7 , where 1 denotes the highest level of freedom and 7 the lowest, the original index values were reversed such that higher numbers denote higher levels of political freedom. The data on these indices was collected for the ten years between 2003 and 2012 whereas their correlation varied from $\mathrm{r}=0.95$ to 0.98 $(\mathrm{p}<0.001)$. Hence, a high reliability of this measure was ensured.

\section{Analysis and results}

The results of the descriptive analysis already highlight the importance of distance when measuring the relative proportion of foreign internationalizing SMEs per world region, linked to global business hubs. An examination of Pearson's correlation suggested that connectivity $(\mathrm{r}=0.001, \mathrm{p}=\mathrm{n} . \mathrm{s}$. $)$ did not associate significantly with the dependent variable. Hence, the variable did not fulfil the assumption of a linear relation with the dependent variable, and has thus been dropped out of the model. Geographic distance $(\mathrm{r}=0.652, \mathrm{p}<0.01)$ and psychic distance $(\mathrm{r}=0.544, \mathrm{p}<0.01)$, on the other hand, are both positively associated with the global business hub ratio. Political freedom $(\mathrm{r}=-0.497, \mathrm{p}<0.05)$ is negatively associated with the predicted variable. The covariate population $(\mathrm{r}=0.652, \mathrm{p}<0.01)$ is also positively associated to the global business hub ratio.

The values for skewness and kurtosis for all explaining variables are between -2 and +2 , and therefore considered acceptable in order to assume normal univariate distribution (George \& Mallery, 2010). Multicollinearity was checked by examining the variance inflation factor (VIF) values for all independent and control variables included in the regression models. The VIF values for all variables were below 10.0 (Deer, 


\section{The Importance of Global Business Hubs on Internationalizing SMEs: an empirical analysis of psychic and geographic distance. \\ Pascal Wild}

Table 1. Descriptive statistics of Peason's correlations

\begin{tabular}{llllll}
\hline Variables & $\mathbf{1}$ & $\mathbf{2}$ & $\mathbf{3}$ & $\mathbf{4}$ & $\mathbf{5}$ \\
\hline Population & 1 & & & & \\
\hline Connectivity & 0.207 & 1 & & & \\
\hline $\begin{array}{l}\text { Geographic } \\
\text { Distance }\end{array}$ & $0.457^{*}$ & -0.031 & 1 & & \\
\hline $\begin{array}{llll}\text { Political Freedom } \\
\text { Psychological }\end{array}$ & -0.127 & 0.123 & -0.231 & 1 & 1 \\
$\begin{array}{l}\text { Distance } \\
\text { Global Business }\end{array}$ & 0.084 & -0.247 & 0.165 & $-0.814^{* *}$ & 1 \\
$\begin{array}{l}\text { Hub Ratio } \\
\text { Min }\end{array}$ & 0.001 & $0.652^{* *}$ & $-0.497^{*}$ & $0.544^{* *}$ \\
\hline $\begin{array}{l}\text { Max } \\
\text { Mean }\end{array}$ & 682.00 & 0.44 & 221.80 & 1.50 & 8.92 \\
\hline $\begin{array}{l}\text { Meandard } \\
\text { deviation }\end{array}$ & $16^{\prime} 675.08$ & 0.66 & 5.52 & 1.72 & 28.14 \\
\hline N & $8^{\prime} 746.50$ & 0.14 & 1.99 & 0.94 & 16.87 \\
\hline
\end{tabular}

${ }^{*}$ Correlation is significant at the 0.05 level (two-tailed); ${ }^{* *}$ correlation is significant at the 0.01 level (two-tailed)

2017). Tolerance values denote variability in independent variables that are not explained by other independent variables (Özgener \& Iraz, 2006). The tolerance for all independent and control variables was above the cutoff of 0.10 (Lin, 2008). According the results, problems of multicollinearity are unlikely. The maximum VIF score is 1.96 for control variable corruption, while testing political freedom as a predictor for the global business hub ratio.

The model was tested using hierarchical multiple regression analysis. Results are provided in Table 2. At the first step (baseline model 1), only control variables were included in the regression equation. Overall regression for this first model was highly significant (R2 $=0.60, \mathrm{~F}(2,20)=15.01, \mathrm{p}<0.001)$. Global city population $(\beta=0.60, \mathrm{p}<0.001)$ and political freedom $(\beta$ $=-0.42, p<0.01$ ) were found to have significant effects on the global business hub ratio.

In model 2 the measure for geographic distance was included in the regression equation along with the control variables. Geographic distance was found to have significant effect $(\beta=0.37, \mathrm{p}<0.05)$ on the global business hub ratio. The overall regression in this second model was highly significant $(R 2=0.70, F(1,19)=15.08$, $\mathrm{p}<0.001$ ), with a significant change in $\mathrm{R}$ square over the baseline model $(\Delta \mathrm{R} 2=0.10, \mathrm{p}<0.05)$. Both covariates, global city population and political freedom, were found to have a decreased significant effect on the ratio of Swiss SMEs in global cities of $\beta=0.44$, at a 0.01 level, and $\beta=0.36$, at a 0.1 level (2-tailed).

Model 3 examined the effect of psychic distance on SMEs choices to link their business in a major global city. The overall model was highly significant $(\mathrm{R} 2=0.67$, $\mathrm{F}(1,19)=12.71, \mathrm{p}<0.001)$ with a significant change in $\mathrm{R}$ Square over the baseline model $(\Delta \mathrm{R} 2=0.07, \mathrm{p}<0.1)$. Psychic distance was found to have a significant positive effect ( $\beta=0.45$ ) on the significance level of $p<0.1$. Both covariates had a significant positive effect on the predicted variable. Global city population had a positive effect of $\beta=0.61 \quad(p<0.1)$ whereas the negative effect of political freedom was reduced to $\beta=-.06$ at a significance level of $\mathrm{p}<0.1$.

Model 4 represents the final model with both, physical and psychic distance included in the regression results. Political Freedom has a minor significant and very weak positive effect of $\beta=0.02$ on a significant level of $p<0.1$, whereas the second covariate population had a significant positive effect of $\beta=0.44(p<0.01)$. Both physical and psychic distance positively affect the global business hub ratio by $\beta=0.38(\mathrm{p}<0.01)$ and $\beta=0.46(\mathrm{p}<$ 0.05). The overall regression in this model was highly significant $(\mathrm{R} 2=0.78, \mathrm{~F}(2,18)=7.08, \mathrm{p}<0.001)$, with a 


\section{The Importance of Global Business Hubs on Internationalizing SMEs: an empirical analysis of psychic and geographic distance.}

\section{Pascal Wild}

Table 2. Regression results for the global business hub ratio

\begin{tabular}{lllll}
\hline Predictors & $\begin{array}{l}\text { Model1 } \\
\text { (baseline) }\end{array}$ & Model 2 & Model 3 & Model 4 \\
\hline Political Freedom & $-0.42^{* *}$ & $-0.36^{*}$ & $-0.06 \mathrm{t}$ & $0.02 \mathrm{t}$ \\
\hline Population & $0.60^{* * *}$ & $0.44^{* *}$ & $0.61^{*}$ & $0.44^{* *}$ \\
\hline Geographic Distance & & $0.37^{*}$ & & $0.38^{* *}$ \\
\hline Psychic Distance & & & 0.451 & $0.46^{*}$ \\
\hline Constant & & & \\
\hline $\boldsymbol{N}$ & 23 & 23 & 23 & 23 \\
\hline Mean model VIF & 1.02 & 1.21 & 2.33 & 2.15 \\
\hline R Square & 0.60 & 0.70 & 0.67 & 0.78 \\
\hline R Square Change & & $0.10^{*}$ & $0.07^{* *}$ & $0.18^{* * *}$ \\
\hline Adjusted R Square & 0.56 & 0.66 & 0.62 & 0.73 \\
\hline $\boldsymbol{F}$ & 15.08 & 15.08 & 12.72 & 15.62 \\
\hline
\end{tabular}

*Significant at the 0.05 level (two-tailed); ${ }^{* *}$ significant at the 0.01 level (two-tailed); ${ }^{* * *}$ significant at the 0.001 level (two tailed); 1 significant at the 0.1 level (two-tailed)

meaningful change in $\mathrm{R}$ square over the baseline model $(\Delta \mathrm{R} 2=0.18, \mathrm{p}<0.01)$.

To conclude, we believe that $\mathrm{H} 2$ and $\mathrm{H} 3$ are confirmed given the significant positive correlation between geographic and psychic distance and the global business hub ratio. H1, which argues that a global business hub's connectivity influences the number of SMEs that internationalize to the world region and that are linked to its hub needs to be rejected. It has not been adequately tested in this study, since the major assumption of a linear relation with the dependent variable was not fulfilled.

\section{Discussion and Limitations}

By analyzing empirical data, this study focused on the importance of global business network hubs in global cities for internationalizing hi-tech SMEs. On the one hand, previous theory suggested that SME internationalization towards distant and culturally unfamiliar markets requires a preceding process of incremental learning in nearby foreign markets (Clark \& Pugh, 2001; Moen, Gavlen, \& Endresen, 2004; Ojala \& Tyrväinen, 2006). A strong position in powerful business networks, on the other hand, explained the rapid processes of SME internationalization, such as of INV's or Born- and Re-Born-global firms (Zahra, 2005; Zhou et al. 2007). The debate on whether a rapid process of internationalization from INVs, mostly shown by SMEs and Startups in fields such as ICT, hi-tech, or (specialized) services, fits with a gradual and stepwise model as depicted in the Nordic school, seems to be clarified by the arguments of Johanson and Vahlne
(2009) and their network-view of the internationalization process. Accordingly, SME internationalization takes place in business networks that are "borderless". Hence, the liability of "outsidership" (coming across as an "outsider" to the relevant business networks) weighs heavier on internationalizing SMEs than any intercultural issues given by "foreignness" (being not a "national", but rather a "foreigner" and thus not familiar with local language and business habits).

The authors also argue that despite the phenomena of born globals with respect to INVs, most internationalizing SMEs are rather "regionals, with international activities that do not really span the globe in any significant fashion". We believe that the network characteristics of internationalizing SMEs, whether INVs or gradually internationalizing companies, significantly changes as their business expands towards more geographically and psychically distant regions. Complex social networks execute over network hubs, with strongly interconnected nodes, while the number of nodes counted in a network hub rises with its increasing complexity (Barabasi \& Albert, 1999; Albert et al. 2000; Leppin et al. 2018). SMEs with geographically widespread business activities, such as in the case of the hi-tech SMEs we studied in Switzerland, need to operate along a far-reaching and complex business network in which geographic and intercultural distances are long. The internationalizing SMEs' burden of mediating intercultural differences and managing tangible and intangible resources across geographic distances and time zone remains, despite the borderless characteristic of international business networks. This is supports our 


\section{The Importance of Global Business Hubs on Internationalizing SMEs: an empirical analysis of psychic and geographic distance. \\ Pascal Wild}

conclusion that the importance of global business hubs for such SMEs is actually rising.

In an ever more interconnected global business environment, sociologists as well as economists observe the rise in importance of densely connected cities for the global economy (Brenner, 1998; Sassen, 2000, 2004; Acs et al., 2008; Scott \& Scott, 2011; Martinus \& Sigler, 2018). In analyzing the role of global business hubs for internationalizing hi-tech SMEs, we empirically observed that greater distance between home and focal markets raises the relative proportion of foreign SMEs that pursue business activities in a region, and that are actually connected to business actors located in the hubs. Whereas the mere connectivity of a business hub does not influence the presence of internationalizing SMEs, both geographic and psychic distance seem to increase their number. In a network-view in which geographic and psychic distances seem to play a less important role, we actually believe that they influence SMEs' necessity to connect to business actors in global business hubs. This helps them to overcome the liability of network outsidership and increase their access to international opportunity through visible recognition.

The results of the research were drawn from a sample of 609 high-technology SMEs generating the majority of their revenues in foreign markets on two or more continents. Many of them can be categorized "born global" firms or "international new ventures" (INVs). Since the mere identification of internationalizing SMEs among a population of SMEs poses a challenge in itself (Rialp \& Rialp, 2001; Baldegger et al. 2016), sample bias issues cannot be excluded, and thus the generalizability of the findings should be questioned. Moreover, this study was based on internationalizing SMEs from a SMOPEC in a middle European country. For them, the potential scope of foreign markets and their underlying economic development stands in strong contrast to internationalizing SMEs from an emerging economy such as China, India or Brazil, which might internationalize towards economically better-developed markets of the OECD countries. Economic development needs to be considered in this case, since emerging markets consist of less infrastructure, institutional voids (Mair \& Marti, 2009), and thus a higher uncertainty, just to name a few issues.

This contribution follows a path of looking to further integrate social network characteristics into the study of SME internationalization. Further studies addressing the notion of network hubs, also in the case of SME

\section{References}

Acs, Z. J., Bosma, N., \& Sternberg, R. 2008. The entrepreneurial advantage of world cities: evidence from global entrepreneurship monitor data. From Econstor: http://hdl.handle.net/10419/31775

Alderson, A.S., \& Beckfield, J. 2004. Power and Position in the World City System. American Journal of Sociology: 811-851.

Al-Laham, A., \& Souitaris, V. 2008. Network embeddedness and new-venture internationalization: Analyzing international linkages in the German biotech industry. Journal of Business Venturing, 23(5): 567-586.

Anderson, J.C., Håkansson, H., \& Johanson, J. 1994. Dyadic business relationships within a business network context. Journal of marketing, 58(4): 1-15.

Arnone, L., \& Deprince, E. 2016. Small firms internationalization: Reducing the psychic distance using social networks. Global Journal of Business Research, 10(1): 55-63.

Axiala, J., \& Fabro, G. 2009. Economic freedom, civil liberties, political rights and growth: a causality analysis. Spanish Economic Review 11(3): 165-178.

Baldegger, R.J., Wyss, P. 2007. Profiling the hybrid: bornagain global firms. A case study on the internationalisation behavior of mature firms in Switzerland. Bern, Fribourg and New York: Growth Publisher.

Baldegger, R.J. and Wild, P. 2019. Internationalization Behavior of SMEs in the Global Context: Entrepreneurial, Orientation, Speed and Performance.

Baldegger, R.J., Wild, P., and Morel, B. 2016. Swiss International Entrepreneurship Survey 2016: Results of the study on the internationalization of Swiss SMEs

Barabasi, A. 2009. Scale-Free Networks: A Decade and Beyond. Science: 412-413.

Barabasi, A., \& Reka, A. 1999. Emergence of Scaling in Random Networks. Science: 509-512.

Benito, G.R., \& Gripsrud, G. 1992. The Expansion of Foreign Direct Investments: Discrete Rational Location Choices or a Cultural Learning Process. Journal of International Business Studies: 461-476.

Brenner, N. 1998. Global cities, glocal states: global city formation and state territorial restructuring in contemporary Europe. Review of international political economy, 5(1): 1-37.

Caldarelli, G., Capocci, A., Rios, P., \& Munoz, M.A. 2002. Scale-free networks without growth or preferential attachment: Good get richer. arXiv preprint condmat/0207366.

Casson, M. (Ed.). 2013. The Growth of International Business (RLE International Business). Routledge. 


\section{The Importance of Global Business Hubs on Internationalizing SMEs: an empirical analysis of psychic and geographic distance.}

\section{Pascal Wild}

Chetty, Sylvie K. 1999. Dimensions of Internationalization of Manufacturing Firms in the Apparel Industry, European Journal of Marketing, 33 (1-2): 121-142

Clark, Timothy and Derek S. Pugh (2001). Foreign Country Priorities in the Internationalization Process: A Measure and an Exploratory Test on British Firms, International Business Review, 10 (3): 285-303.

Coviello, N.E. 2006. The network dynamics of international new ventures. Journal of international Business studies, 37(5): 713-731.

Cyert, Richard; March, James G. 1992. A Behavioral Theory of the Firm (2 ed.). Oxford: Wiley-Blackwell.

Dawson, J.W. 1998. Institutions, investment, and growth: new cross-country and panel data evidence. Economic Inquiry, 36: 275-288

De Clercq, D., Lim, D.S., \& Oh, C.H. 2014. Hierarchy and conservatism in the contributions of resources to entrepreneurial activity. Small Business Economics, 42(3): 507-522.

Deer, R.J. 2017. Cross-national differences in entrepreneurial activity: role of culture and institutional factors. Small Business Economics: 813842.

Dominguez, N., \& Mayrhofer, U. 2017. Internationalization stages of traditional SMEs: Increasing, decreasing and re-increasing commitment to foreign markets. International Business Review, 26(6): 1051-1063.

Doucouliagos, H., \& Ulubasoglu, M.A. 2008. Democracy and economic growth: a meta-analysis. American Journal of Political Science 52(1): 61-83.

Dow, D. 2000. A Note on Psychological Distance and Export Market Selection. Journal of International Marketing: 51-64.

Eriksson, K., Hohenthal, J., \& Lindbergh, J. 2006. Factors affecting SME export channel choice in foreign markets. Advances in International Marketing, 16: 122.

Erramilli, M.K. 1991. The experience factor in foreign market entry behavior of service firms. Journal of international business studies, 22(3): 479-501.

Friedmann, J. 1995. Where we stand: a decade of world city research. In P. L. Knox, \& P. J. Taylor, World Cities in a World-System. Cambridge: Cambridge University Press: 21-47

Galkina, T., \& Chetty, S. 2015. Effectuation and networking of internationalizing SMEs. Management International Review, 55(5): 647-676.

Gastil, R.D. 1991. Freedom in the world: political rights and civil liberties. Freedom House.

GaWC. 2017. The World According to GaWC 2016. From: http://www.lboro.ac.uk/ gawc/ world2016t.html

George, D., \& Mallery, M. 2010. SPSS for Windows Step by
Step: A Simple Guide and Reference. Boston: Pearson.

Gerring, J., Bond, P., Barndt, W.T. and Moreno, C. 2005. Democracy and economic growth: a histrocial perspective. World Politics: 323-364

Gibson, J. L. 1993. Perceived political freedom in the Soviet Union. The Journal of Politics, 55(04): 936-974.

Gilmore, A., Carson, D., \& Rocks, S. 2006. Networking in SMEs: Evaluating its contribution to marketing activity. International Business Review, 15(3): 278-293.

Goodell, G., \& Powelson, J.P. 1982. The democratic prerequisites of development. New York: Freedom House.

Gritsai, O. 2004. Global Business Services in Moscow: Patterns of Involvement. Urban Studies, 41 (10): 20012024.

Hammer, M., Schüffel, P. and Baldegger, R. 2016. Hub internationalization. Proceedings of the Academy of International Business (AIB) 2016 Annual Meeting. No. CONFERENCE-2016-050. 27-30 June 2016, 2016.

Hofstede, G. 1983. Culture's consequences- international differences in work-related values. Beverly Hills, London: Sage Publications.

Hohenthal, J., Johanson, J., \& Johanson, M. 2015. Network knowledge and business-relationship value in the foreign market. In Knowledge, Networks and Power. Palgrave Macmillan, London: 187-224

Holmlund, M., \& Kock, S. 1998. Relationships and the internationalisation of Finnish small and mediumsized companies. International small business journal, 16(4): 46-63.

Johanson, J., \& Vahlne, J.E. 2009. The Uppsala internationalization process model revisited: From liability of foreignness to liability of outsidership. Journal of International Business Studies.

Johanson, J., \& Vahlne, J.E. $1977 . \quad$ The Internationalization Process of the Firm - A Model of Knowledge Development and Increasing Foreign Market Commitments. Journal of International Business Studies, Vol. 8 No.1: 23-32.

Jones, J.J., Settle, J.E., Bond, R.M., Fariss, C.J., Marlow, C., \& Fowler, J.H. 2013. Inferring tie strength from online directed behavior. PloS one, 8(1).

Kaplan, S., \& Sawhney, M. 2000. E-hubs: the new B2B marketplaces. Harvard business review, 78(3): 97-97.

Kogut, B., \& Singh, H. 1988. The effect of national culture on the choice of entry mode. . Journal of International Business Studies, 19(3): 411-432.

Kurzman, C., Werum, R., \& Burkhart, R.E. 2002. Democracy's effect on economic growth: a poold time-series analysis, 1981-1980. Studies in Comparative International Development, 37(1): 3-33.

Lee, H., \& Yang, H.M. 2003. Strategies for a global logistics and economic hub: Incheon International Airport. Journal of Air Transport Management, 9(2): 113-121. 


\section{The Importance of Global Business Hubs on Internationalizing SMEs: an empirical analysis of psychic and geographic distance.}

\section{Pascal Wild}

Leppin, A.L., Okamoto, J.M., Organick, P.W., Thota, A.D., Barrera-Flores, F.J., Wieland, M.L., \& Montori, V.M. 2018. Applying social network analysis to evaluate implementation of a multisector population health collaborative that uses a bridging hub organization. Frontiers in public health, 6: 315 .

Lin, F. J. 2008. Solving multicollinearity in the process of fitting regression model using the nested estimate procedure. Quality \& Quantity 42(3): 417-426.

Madsen, T.K., \& Servais, P. 1997. The internationalization of born globals: an evolutionary process?. International business review, 6(6): 561-583.

Madsen, T.K., \& Servais, P. 1997. The internationalization of born globals: an evolutionary process?. International business review, 6(6): 561-583.

Mair, J., \& Marti, I. 2009. Entrepreneurship in and around institutional voids: A case study from Bangladesh. Journal of business venturing, 24(5): 419435.

Martinus, K., \& Sigler, T.J. 2018. Global city clusters: theorizing spatial and non-spatial proximity in interurban firm networks. Regional studies, 52(8): 10411052.

Merton, R. K. 1968. "The Matthew Effect in Science" (PDF). Science. 159 (3810): 56-63.

Munir, Q., Kok, S.C., Teplova, T., \& Li, T. 2017. Powerful CEOs, debt financing, and leasing in Chinese SMEs: Evidence from threshold model. The North American Journal of Economics and Finance, 42: 487-503.

Munir, Q., Kok, S.C., Teplova, T., \& Li, T. 2017. Powerful CEOs, debt financing, and leasing in Chinese SMEs: Evidence from threshold model. The North American Journal of Economics and Finance, 42: 487-503.

Musteen, M., Francis, J., \& Datta, D.K. 2010. The influence of international networks on internationalization speed and performance: A study of Czech SMEs. Journal of World Business, 45(3): 197205.

O'Grady, S., \& Lane, H.W. 1996. The Psychic Distance Paradox. Journal of International Business Studies, 2nd Qtr., Vol. 27, No. 2: 309-333.

Ojala, Arto and Tyrväinen, Pasi. 2006. Business Models and Market Entry Mode Choice of Small Software Firms, Journal of International Entrepreneurship: 6981

Ojala, Arto and Tyrväinen, Pasi. 2007. Market Entry and Priority of Small and Medium-Sized Enterprises in the Software Industry: An Empirical Analysis of Cultural Distance, Geographic Distance, and Market Size. Journal of International Marketing: 123-149.

Olds, K., \& Yeung, H. 2011. Pathways to global city formation: a view from the developmental city-state of Singapore. Review of International Political Economy: 458-521.

Onkelinx, J., and Sleuwaegen, L. 2010. Internationalization strategy and performance of small and medium sized enterprises. Working paper Brussels: National Bank of Belgium.

Oviatt, B.M., McDougall, P.P. 1994. Towards a theory of international new ventures. Journal of International Business Studies, Vol. 1: 45-64.

Özgener, S., \& Iraz, R. 2006. Customer relationship management in small-medium enterprises: the case of Turkish tourism industry. Tourism Management, S. 1356-1363.

Rialp, A., \& Rialp, J. 2001. Conceptual frameworks on SMEs' internationalization: Past, present and future trends of research. Von Reassesing the Internationlization of the Firm. http://dx.doi.org/10.1016/S1474-7979(01)11016-1 abgerufen

Rugman, A.M., \& Verbeke, A. 1993. Foreign subsidiaries and multinational strategic management: An extension and correction of Porter's single diamond framework. MIR: Management International Review: 71-84.

Ruzzier, M., \& Antoncic, B. 2007. Social Capital and SME Internationalization: An Empirical Examination. Transformations in Business \& Economics, 6(1).

Sassen, S. 1994. Cities in a World Economy. Thousand Oaks, California: Pine Forge Press.

Sassen, S. 2000. The Global City: The Denationalizing of Time and Space. In J. Ockman, The Pragmatist Imagination: Thinking about "Things in the Making". Princeton, NJ: Princeton Architectural Press: 254-265

Sassen, S. 2001. The Global City, 2nd edition. Princeton: Princeton University Press.

Sassen, S. 2004. The Global city: Introducing a Concept. Brown J. World Aff., 11:27.

Sassen, S. 2005. The Global City: Introducing a Concept. The Brown Journal of World Affairs, Volume 11, Issue 2: 27-43.

Schwab, K., Sala-i-Martin, X., Samans, R., \& Blanke, J. 2016. Global Competitiveness Report 2015-2016. World Economic Forum.

Scott, A.J. 2011. Global City-Regions: Trends, Theory, Policy. Oxford: Oxford University Press.

Scully, G.W. 1988. The institutional framework and economic development. The Journal of Political Economy: 652-662.

Senik, Z.C., Scott-Ladd, B., Entrekin, L., \& Adham, K.A. 2011. Networking and internationalization of SMEs in emerging economies. Journal of International Entrepreneurship, 9(4): 259-281.

Sethi, S.P. 1971. "Comparative Cluster Analysis for World Markets." Journal of Marketing Research 8, : 348-354.

Sirowy, L., \& Inkeles, A. 1990. The effects of democracy on economic growth and inequality: a 


\section{The Importance of Global Business Hubs on Internationalizing SMEs: an empirical analysis of psychic and geographic distance. \\ Pascal Wild}

review. Studies in Comparative International Development: 126-157.

Styles, C., Loane, S., \& Bell, J. 2006. Rapid internationalisation among entrepreneurial firms in Australia, Canada, Ireland and New Zealand. International marketing review.

Tachiki, D. 2005. Between Foreign Direct Investment and Regionalism: The Role of Japanese Production Networks. In J. T. Pempel, Remapping East Asia: The Construction of a Region (S. 149-169). New York: Cornell University Press.

Talebi, K., Tajeddin, M., Rastgar, A.A., \& Emami, A. 2017. Internationalization of SMEs and organizational factors in emerging economies: High-tech industry of Iran. International Journal of Academic Research in Business and Social Sciences, 7(1): 178-92.

Taylor, P.J., Walker, D.R., \& Beaverstock, J.V. 2002. Firms and their global service networks. In S. Sassen, Global networks, linked cities. New York: Routledge: 93-115.

Teece, D.J. 1981. The market for know-how and the efficient international transfer of technology. The Annals of the American Academy of Political and Social Science, 458(1): 81-96.

United Nations. 2018. Statistics Division. Von Methodology: Standard country or area codes for statistical use https://unstats.un.org/unsd/methodology/m49/ abgerufen

United Nations Statistics Division. 2017. UN Statistics Division Methodology. Von Standard country area codes for statistical use (M49): https://unstats.un.org/unsd/methodology/m49/ abgerufen

Wild, P. 2019. Firm Internationalization and Global Cities: Exploring the Role of Singapore for Swiss SMEs in Southeast Asia. Université de Genève. Thèse. doi: $\quad$ 10.13097/archive-ouverte/unige:120462 https://archive-ouverte.unige.ch/unige:120462

Wiliamson, O.E. 2000. The new institutional economics: taking stock, looking ahead. Journal of Economic Literature: 595-613.

Woo-Cumings, M. 2005. The Political Economy of Growth in East Asia: A Perspective on the State, Market, and Ideology. In A. Masahiko, K. Hyung-Ki, \& M. Okuno-Fujiwara, The Role of Government in East Asian Economic Development: Comparative. Oxford: Oxford University Press: 323-341.

Wu, W., \& Davis, O.A. 1999. The two freedoms, economic growth and develoopment: an empirical study. Public Choice, 100(1-2): 39-64.

Zain, M., \& Ng, S.I. 2006. The impacts of network relationships on SMEs' internationalization process. Thunderbird international business review, 48(2): 183-205.

Zäpfel, G., \& Wasner, M. 2002. Planning and optimization of hub-and-spoke transportation networks of cooperative third-party logistics providers. International Journal of Production Economics, 78(2): 207-220.

Zhang, X., Ma, X., Wang, Y., Li, X., \& Huo, D. 2016. What drives the internationalization of Chinese SMEs? The joint effects of international entrepreneurship characteristics, network ties, and firm ownership. International Business Review, 25(2): 522-534.

Zhou, L., Wu, W.P., \& Luo, X. 2007. Internationalization and the performance of born-global SMEs: the mediating role of social networks. Journal of international business studies, 38(4): 673-690.

\section{About the Author}

Pascal Wild is an Assistant Professor at the School of Management Fribourg (member of the University of Applied Sciences and Arts Western Switzerland [HES-SO]) and teaches undergraduate and graduate students. He holds a Master of Science in Business Administration and a $\mathrm{PhD}$ in Social Sciences (orientation Socioeconomics) from the University of Geneva. His research interests lie in the areas of international entrepreneurship, global cities, and emerging markets.

Citation: Wild, P. 2020. The importance of global business hubs on internationalizing SMEs: an empirical analysis of psychic and geographic distance. Technology Innovation Management Review, 10(4): 35-47. http://doi.org/10.22215/timreview/1345

Keywords: SME internationalization, international entrepreneurship Network view, Business network hubs, Liability of foreignness. 